\title{
PENGENAAN PAJAK PERTAMBAHAN NILAI TERHADAP JASA INTERMEDIASI KEUANGAN PERBANKAN DI INDONESIA
}

\author{
Setiadi Alim Lim \\ Program Studi Akuntansi Politeknik Ubaya \\ Jalan Ngagel Jaya Selatan 169, Surabaya
}

\begin{abstract}
Most countries that use the Value Added Tax system are generally exclude financial intermediation services of imposition of Value Added Tax. This exception in addition to reduce the country revenue from tax sector in significant numbers, also gives rise to distortions in terms of both legal and economical. But after the financial crisis in 2008, many countries have began to rethink to impose value added tax on financial intermediation services. There are several alternative methods are expected to be implemented to overcome the difficulties the imposition of VAT on financial intermediation services. Indonesia as one of the countries that use the Value Added Tax system also excludes the imposition of VAT on financial intermediation services. In order to increase country revenue from the tax sector, the Indonesia should consider eliminating VAT exemption for financial intermediation services.
\end{abstract}

\begin{abstract}
ABSTRAK
Kebanyakan negara yang menggunakan sistem Pajak Pertambahan Nilai umumnya mengecualikan jasa intermediasi keuangan dari pengenaan Pajak Pertambahan Nilai. Pengecualian ini di samping mengurangi penerimaan negara dari sektor pajak dalam jumlah yang signifikan, juga mengakibatkan timbulnya distorsi baik dari segi legal maupun ekonomis. Namun pasca terjadinya krisis keuangan pada tahun 2008, banyak negara mulai berpikir ulang untuk mengenakan Pajak Pertambahan Nilai pada jasa intermediasi keuangan. Ada beberapa alternatif metode yang diharapkan dapat diimplementasikan untuk mengatasi kesulitan pengenaan Pajak Pertambahan Nilai terhadap jasa intermediasi keuangan. Indonesia sebagai salah satu negara yang menggunakan sistem Pajak Pertambahan Nilai juga mengecualikan pengenaan Pajak Pertambahan Nilai terhadap jasa intermediasi keuangan. Dalam rangka meningkatkan penerimaan negara dari sektor pajak, Indonesia seharusnya mempertimbangkan menghapuskan pengecualian pengenaan Pajak Pertambahan Nilai terhadap jasa intermediasi keuangan.
\end{abstract}


Keywords: financial intermediation services, exemption, cascading, reverse charge.

\section{PENDAHULUAN}

Dalam rangka membiayai pengeluarannya, negara-negara di dunia terutama mengharapkan sumber pemasukan dari pajak. Salah satu pemasukan dari sektor pajak bersumber dari pajak tidak langsung. Setiap negara dapat menggunakan sistem pemungutan pajak tidak langsung yang berbedabeda. Namun sejak sistem Pajak Pertambahan Nilai (Value Added Tax) mulai dipopulerkan pada awal tahun 1970-an, kebanyakan negara-negara di seluruh dunia mulai mengubah sistem pemungutan pajak tidak langsungnya menjadi sistem Pajak Pertambahan Nilai. Gale and Harris (2011) menyatakan Pajak Pertambahan Nilai sudah digunakan di 150 negara di seluruh dunia, dan semua negara OECD lain di luar Amerika Serikat sudah menggunakan sistem Pajak Pertambahan Nilai.

Pajak Pertambahan Nilai akan dikenakan terhadap transaksi penyerahan barang dan jasa. Sistem Pajak Pertambahan Nilai menganut sistem multi stage, artinya Pajak Pertambahan Nilai akan dikenakan pada setiap rantai tahapan produksi dan distribusi. Namun pemungutan Pajak Pertambahan Nilai pada setiap tahapan produksi dan distribusi tidak dilakukan terhadap seluruh nilai barang dan jasa, melainkan hanya atas tambahan nilai barang dan jasa yang terjadi pada setiap tahapan produksi dan distribusi, termasuk laba. Pemungutan Pajak Pertambahan Nilai akan berakhir apabila barang dan jasa tersebut telah sampai kepada konsumen akhir.

Pajak Pertambahan Nilai umumnya tidak diberlakukan untuk semua penyerahan barang dan jasa. Ada barang-barang dan jasa-jasa karena pertimbangan tertentu dikecualikan dari pengenaan Pajak Pertambahan Nilai. Barang dan jasa yang dikecualikan dari pengenaan Pajak Pertambahan Nilai biasanya adalah barangbarang dan jasa-jasa yang merupakan kebutuhan pokok mendasar masyarakat banyak atau untuk tujuan-tujuan sosial. Mengenai jenis barang dan jasa yang dikecualikan dari pengenaan Pajak Pertambahan Nilai tergantung kebijakan dari masing-masing negara.

Salah satu jenis jasa yang dikecualikan dari pengenaan Pajak Pertambahan Nilai adalah jasa keuangan. Kebanyakan negara yang menggunakan sistem Pajak Pertambahan Nilai (Value Added Tax) memilih mengecualikan berbagai jasa keuangan sebab kesulitan untuk mengukur biaya keuangan implisit (Merrill, 2011). KPMG (2013) menyatakan kebanyakan negara yang mengecualikan jasa keuangan dari pengenaan Pajak Pertambahan Nilai didasarkan pada 2 alasan utama, yaitu: (i) kesulitan dalam mengukur nilai tambah jasa keuangan pada basis transaction-by-transaction; (ii) Jasa keuangan memfasilitasi pembelian dan penjualan barang dan jasa. Menurut Zee (2004) sebagian besar dari lebih 120 negara yang menganut sistem Pajak Pertambahan Nilai mengecualikan sektor jasa keuangan dari pengenaan Pajak Pertambahan Nilai dengan derajat yang bervariasi. Erbe and Buttner (2013) menyatakan bahwa pengecualian Pajak Pertambahan Nilai 
untuk jasa keuangan diaplikasikan secara luas.

Pengecualian pengenaan Pajak Pertambahan Nilai akan mengurangi pendapatan pemerintah dari Pajak Pertambahan Nilai. Genser and Winker (1998) serta Huizinga (2002) dalam Erbe and Buttner (2013) menyatakan pencabutan pengecualian pengenaan Pajak Pertambahan Nilai terhadap jasa keuangan mungkin akan menghasilkan keuntungan pendapatan yang sangat substansial.

Erbe and Buttner (2013) menyatakan di samping keuntungan pendapatan dari pengenaan Pajak Pertambahan Nilai untuk sektor keuangan, distorsi dari pengecualian pengenaan Pajak Pertambahan Nilai untuk jasa keuangan menjadi diskusi di dalam literatur. Cottarelli (2010) menyatakan mengalami kesulitan ketika pimpinan dari G-20 meminta diberikan pandangan pada pertemuan bulan Juni 2010 mengenai opsi negaranegara mengadopsi atau mempertimbangkan bagaimana sektor keuangan dapat membuat kontribusi yang adil dan substansial ke depannya untuk membayar beban yang berhubungan dengan intervensi pemerintah guna memperbaiki sistem perbankan.

Jadi kebanyakan negara yang menganut sistem Pajak Pertambahan Nilai mengecualikan jasa keuangan dari pengenaan Pajak Pertambahan Nilai, terutama karena alasan kesulitan untuk menghitung nilai tambahnya. Konsekwensi dari tidak dikenakannya Pajak Pertambahan Nilai terhadap jasa keuangan adalah berkurangnya pendapatan negara dari Pajak Pertambahan Nilai. Jumlah sumber pemasukan negara yang berkurang karena pengecualian pengenaan Pajak Pertambahan Nilai cukup besar. Merrill (2011) menyebutkan jasa keuangan mewakili $14 \%$ dari potensial dasar pemajakan pada Pajak Pertambahan Nilai di Amerika Serikat. Di samping itu pengecualian pengenaan Pajak Pertambahan Nilai menimbulkan suatu distorsi, karena memberikan suatu perlakuan istimewa pada usaha jasa keuangan yang mana hal ini tidak didapat oleh bidang usaha yang lain.

Pada saat terjadi krisis keuangan tahun 2008, sebagian besar negara yang mengalami krisis keuangan mengeluarkan dana dalam jumlah yang sangat besar untuk melakukan bail out pihak perbankan dan penyedia jasa keuangan lainnya. Hal ini dilakukan dalam rangka menyelamatkan ekonominya agar terhindar dari efek domino krisis keuangan yang dimulai dari mismanagement pihak perbankan dan lembaga keuangan lainnya dengan produk subprime mortgage. Dari krisis keuangan ini nampak bahwa pemerintah suatu negara akan mengeluarkan dana yang sangat besar untuk melakukan intervensi pada usaha perbankan dan jasa keuangan, yang mana selama ini kontribusi pemasukan pajak dari usaha jasa keuangan sangat minim sekali karena dibebaskannya transaksi jasa keuangan dari pengenaan Pajak Pertambahan Nilai. Hal ini kemudian memicu timbulnya desakan untuk mempertimbangkan lagi kebijakan mengecualikan jasa keuangan dari pengenaan Pajak Pertambahan Nilai.

Tulisan ini akan membahas bagaimana pengenaan Pajak Pertambahan Nilai terhadap jasa keuangan di Indonesia, khususnya jasa intermediasi keuangan yang disediakan oleh perbankan. Apakah Indonesia saat ini seperti kebanyakan negara-negara lain di dunia yang menggunakan sistem Pajak Pertambahan Nilai juga menge- 
cualikan pengenaan Pajak Pertambahan Nilai untuk jasa intermediasi keuangan perbankan? Untuk ke depannya apakah pengecualian pengenaan Pajak Pertambahan Nilai terhadap jasa intermediasi keuangan perbankan masih tepat untuk diterapkan di Indonesia?

\section{JASA KEUANGAN}

Jasa keuangan bisa diartikan sebagai sesuatu yang dapat digunakan oleh konsumen dan bisnis untuk memperoleh barang-barang keuangan seperti pinjaman dan asuransi (Asmundson, 2011). Menurut Sutton and Jenkins (2007) sektor jasa keuangan berhubungan dengan bisnis yang luas dan terdiri dari bank komersial, perusahaan kartu kredit, broker saham, perusahaan asuransi dan lainnya.

Bisnis jasa keuangan berperanan penting dalam menggerakkan roda perekonomian suatu negara. Hal ini seperti diungkapkan oleh Ardic et al. (2011) bahwa ada hubungan yang erat antara pengembangan keuangan dan pertumbuhan ekonomi. Pendapat senada diungkapkan oleh Sutton and Jenkins (2007) yang menyatakan jasa keuangan adalah hal mendasar untuk pertumbuhan dan pegembangan ekonomi. Lebih lanjut Mujeri (2015) menyatakan akses terhadap keuangan khususnya bagi masyarakat miskin adalah hal yang esensial untuk mempromosikan pertumbuhan ekonomi inklusif dan memberantas kemiskinan di suatu negara. Akses terhadap keuangan disediakan oleh penyedia jasa keuangan. Asmundson (2011) menyatakan bisnis jasa keuangan adalah bisnis perantara. Bisnis jasa keuangan akan menyalurkan uang dari penyimpan kepada peminjam. Bebe- rapa produk jasa keuangan yang disediakan oleh lembaga penyedia jasa keuangan antara lain: rekening giro bank, deposito, pinjaman/kredit, kartu kredit, leasing, berbagai macam asuransi, hipotik dan lainnya.

Salah satu lembaga penyedia jasa keuangan adalah lembaga perbankan. Beberapa jasa keuangan yang disediakan lembaga perbankan antara lain adalah rekening giro, deposito, kredit, inkaso, clearing, jual beli valuta asing, kartu kredit, penyewaan safety box dan jasa-jasa perbankan lainnya.

\section{PAJAK PERTAMBAHAN NILAI}

Pajak Pertambahan Nilai adalah jenis pajak tidak langsung yang digunakan banyak negara di seluruh dunia. Keen and Lockwood (2007) menyatakan lima puluh tahun yang lalu Pajak Pertambahan Nilai masih jarang terdengar di luar Perancis. Sekarang Pajak Pertambahan Nilai menghasilkan $20 \%$ dari pendapatan pajak dunia dan mempengaruhi kehidupan 4 milyar orang. Menurut Holcombe (2010) Pajak Pertambahan Nilai memberikan kontribusi yang sangat signifikan bagi pendapatan pajak di negara-negara Uni Eropa dan kebanyakan negara maju di seluruh dunia. Untuk keseluruhan negara Uni Eropa, Pajak Pertambahan Nilai memberikan kontribusi $30 \%$ dari seluruh pendapatan pajak. Gale and Harris (2011) menyebutkan di luar Amerika Serikat, pada negara-negara OECD dalam tahun 2006, Pajak Pertambahan Nilai menghasilkan pendapatan hampir 7\% dari GDP (Gross Domestic Product) dan hampir 19\% dari pendapatan yang diperoleh negara pada semua level. 
Negara yang menggunakan sistem Pajak Pertambahan Nilai akan menentukan jenis barang dan jasa yang setiap penyerahannya akan dikenakan Pajak Pertambahan Nilai (objek Pajak Pertambahan Nilai). Barang dan jasa yang atas penyerahannya dikenakan Pajak Pertambahan Nilai biasanya disebut sebagai Barang Kena Pajak (BKP) dan Jasa Kena Pajak (JKP). Sedangkan barang dan jasa yang penyerahannya tidak dikenakan Pajak Pertambahan Nilai disebut bukan Barang Kena Pajak dan bukan Jasa Kena Pajak. Selain penentuan objek yang dikenakan Pajak Pertambahan Nilai, peraturan pajak di suatu negara biasanya juga mengatur tentang batasan subjek Pajak Pertambahan Nilai, artinya mengatur pihak-pihak mana yang harus memugut Pajak Pertambahan Nilai atas penyerahan Barang Kena Pajak dan Jasa Kena Pajak. Pihak yang wajib memungut Pajak Pertambahan Nilai atas penyerahan Barang Kena Pajak dan atau Jasa Kena Pajak dikenal dengan nama Pengusaha Kena Pajak (PKP).

Pada saat menyerahkan Barang Kena Pajak dan atau Jasa Kena Pajak, Pengusaha Kena Pajak harus menerbitkan bukti pemungutan Pajak Pertambahan Nilai yang biasa dikenal dengan nama Faktur Pajak. Pajak Pertambahan Nilai yang dipungut oleh Pengusaha Kena Pajak pada saat menyerahkan Barang Kena Pajak dan atau Jasa Kena Pajak disebut sebagai Pajak Pertambahan Nilai Keluaran atau disingkat PPN Keluaran. Sedangkan Pajak Pertambahan Nilai yang dibayar pada saat Pengusaha Kena Pajak menerima penyerahan Barang Kena Pajak dan atau Jasa Kena Pajak disebut sebagai Pajak Pertambahan
Nilai Masukan atau disingkat PPN Masukan.

Pada suatu periode tertentu yang biasa dikenal sebagai masa pajak (biasanya 1 bulan), Pengusaha Kena Pajak akan memperhitungkan jumlah PPN Keluaran dan jumlah PPN Masukan pada masa pajak tersebut. Apabila jumlah PPN Keluaran lebih besar dari pada PPN Masukan, maka terjadi kurang bayar. Pengusaha Kena Pajak harus menyetorkan jumlah kurang bayar tersebut yang merupakan selisih antara jumlah PPN Keluaran dan PPN Masukan ke kantor pajak. Sedangkan apabila jumlah PPN Keluaran lebih kecil dari pada jumlah PPN Masukan, maka akan terjadi lebih bayar. Pengusaha Kena Pajak dapat meminta kembali (restitusi) jumlah lebih bayar tersebut ke kantor pajak.

\section{PENGECUALIAN PENGENAAN PAJAK PERTAMBAHAN NILAI}

Karena pertimbangan-pertimbangan tertentu biasanya setiap negara yang menerapkan sistem Pajak Pertambahan Nilai melakukan pengecualian terhadap subjek-subjek dan objek-objek Pajak Pertambahan Nilai tertentu. Pengecualian subjek dilakukan apabila transaksi yang melibatkan subjek Pajak Pertambahan Nilai tertentu tidak dipungut Pajak Pertambahan Nilainya, walaupun objek yang dijadikan transaksi termasuk objek Pajak Pertambahan Nilai. Penentuan subjek yang dikecualikan sebagai subjek Pajak Pertambahan Nilai biasanya ditentukan berdasarkan jumlah nilai barang dan jasa yang diserahkan dalam 1 tahun pajak. Batas jumlah nilai barang dan jasa yang diserahkan itu biasa disebutkan sebagai Value Added Tax Threshold. Apabila subjek menyerahkan barang dan jasa dengan jumlah 
nilai dalam 1 tahun di bawah Value Added Tax Threshold, maka subjek tersebut dikecualikan sebagai subjek Pajak Pertambahan Nilai dan tidak memungut Pajak Pertambahan Nilai, walaupun menyerahkan barang dan jasa yang termasuk objek Pajak Pertambahan Nilai. Sedangkan pengecualian objek dilakukan jika transaksi yang berhubungan dengan objek Pajak Pertambahan Nilai tertentu tidak dikenakan Pajak Pertambahan Nilai, walaupun subjek yang terlibat dalam transaksi adalah subjek Pajak Pertambahan Nilai.

Dari kedua macam pengecualian yang dilakukan, pengecualian terhadap objek Pajak Pertambahan Nilai yang umumnya mempunyai dampak negatif yang besar. Di samping mengurangi jumlah penerimaan Pajak Pertambahan Nilai dalam jumlah yang signifikan, pengecualian terhadap objek Pajak Pertambahan Nilai juga biasanya berakibat memutuskan rantai pemungutan Pajak Pertambahan Nilai.

Le (2003) menyatakan pengecualian cenderung akan mengerosi dasar pemungutan Pajak Pertambahan Nilai, mengurangi pengumpulan pendapatan dari Pajak Pertambahan Nilai di satu sisi, memutus rantai pemungutan Pajak Pertambahan Nilai dan dengan demikian menyebabkan masalah "cascading" di sisi lain.

Bird (2005) dalam Smith et al. (2011) menyatakan pengecualian pasti membuat Pajak Pertambahan Nilai menjadi lebih sempit dan untuk alasan ini umumnya pengecualian dibatasi pada barang makanan yang bersifat mendasar, jasa kesehatan dan jasa pendidikan. Pengecualian, oleh karenanya meningkatkan "cascading" dan memutus rantai Pajak Pertambahan Nilai yang dapat membuat efektivitas penegakan hukum lebih sulit dilakukan.

Menurut Mackenzie (1991) dalam suatu dunia yang berasumsi tidak ada biaya untuk administrasi pajak, maka tidak ada alasan untuk mengecualikan aktivitas-aktivitas khusus dari pengenaan Pajak Pertambahan Nilai, kecuali kemungkinan dalam kasus aktivitas-aktivitas tertentu di mana Pajak Pertambahan Nilai sulit untuk didefinisikan. Pengenaan Pajak Pertambahan Nilai dengan tarif 0\% terhadap barang dan jasa adalah instrumen yang jauh lebih baik dari pada pengecualian untuk mencapai distribusi sasaran.

Pada dasarnya pengecualian pengenaan Pajak Pertambahan Nilai mempunyai dampak yang negatif bagi penerapan sistem Pajak Pertambahan Nilai di suatu negara. Di samping mengurangi jumlah penerimaan Pajak Pertambahan Nilai yang sangat signifikan, juga akan memutus rantai pengenaan Pajak Pertambahan Nilai. Karenanya setiap negara yang menerapkan sistem Pajak Pertambahan Nilai sudah seharusnya mengurangi jumlah subjek dan objek Pajak Pertambahan Nilai yag dikecualikan. Namun Mackenzie (1991) menyatakan bahwa banyak negara berkembang yang menganut sistem Pajak Pertambahan Nilai mengecualikan dalam jumlah yang besar barang dan jasa yang tidak dipungut Pajak Pertambahan Nilai.

Feria and Krever (2013) menyatakan obyek standar yang dikecualikan dari pengenaan Pajak Pertambahan Nilai di negara-negara Eropa terdiri dari: jasa pos, transpor orang sakit/terluka, perawatan rumah sakit dan medis, darah manusia, jaringan dan organ, perawatan gigi, pendidikan, 
kegiatan olahraga, jasa yang berkaitan dengan budaya (tidak termasuk penyiaran radio dan televisi), pekerjaanpekerjaan sosial, kegiatan non komersial oleh organisasi nirlaba, kegiatan penggalangan dana tertentu, penyerahan tanah dan bangunan (termasuk harta yang tidak bergerak), taruhan, lotere dan perjudian, asuransi dan reasuransi, dan sejumlah jasa keuangan, termasuk jasa perantara pinjaman dan operasi yang berkaitan dengan pengelolaan dana/modal.

Indonesia merupakan salah satu negara berkembang yang sudah lama menggunakan sistem Pajak Pertambahan Nilai untuk memungut pajak tidak langsung, yaitu lebih dari 30 tahun. Seperti negara-negara lain yang menggunakan sistem Pajak Pertambahan Nilai, khususnya negara-negara berkembang, Undang-Undang Pajak Pertambahan Nilai di Indonesia juga melakukan pengecualian subjek dan pengecualian objek Pajak Pertambahan Nilai. Pengecualian subjek pajak diatur dalam pasal 3A ayat (1) Undang-Undang Nomor 8 Tahun 1983 tentang Pajak Pertambahan Nilai sebagaimana telah diubah beberapa kali, terakhir dengan Undang-Undang Nomor 42 Tahun 2009 yang menyebutkan pengusaha kecil dikecualikan dari kewajiban memungut, menyetor dan melaporkan Pajak Pertambahan Nilai yang terutang.

Kemudian di dalam Peraturan Menteri Keuangan Nomor 68/PMK. 03/2010 tanggal 23 Maret 2010 tentang Batasan Pengusaha Kecil Pajak Pertambahan Nilai yang telah diubah dengan Peraturan Menteri Keuangan Nomor 197/PMK.03/2013 tanggal 20 Desember 2013 tentang Perubahan Peraturan Menteri Keuangan Nomor 68/PMK.03/2010 tanggal 23 Maret
2010 tentang Batasan Pengusaha Kecil Pajak Pertambahan Nilai pasal I ayat (1) disebutkan pengusaha kecil merupakan pengusaha yang selama 1 (satu) tahun buku melakukan penyerahan Barang Kena Pajak dan/atau Jasa Kena Pajak dengan jumlah peredaran bruto dan/atau penerimaan bruto tidak lebih dari Rp. 4.800.000.000,-.

Jadi Sistem Pajak Pertambahan Nilai di Indonesia mengecualikan subjek yang menyerahkan barang dan jasa obyek Pajak Pertambahan Nilai dengan jumlah nilai penyerahan pertahun tidak lebih dari Rp. 4.800.000.000,- sebagai subjek Pajak Pertambahan Nilai. Nilai Rp. 4.800.000.000,- ini yang disebut Value Added Tax Threshold.

Sedangkan pengecualian objek Pajak Pertambahan Nilai diatur dalam pasal 4A Undang-Undang Nomor 8 Tahun 1983 tentang Pajak Pertambahan Nilai sebagaimana telah diubah beberapa kali, terakhir dengan Undang-Undang Nomor 42 Tahun 2009. Pada ayat (2) pasal ini disebutkan jenis barang yang tidak dikenai Pajak Pertambahan Nilai, yaitu: (a) barang hasil pertambangan atau hasil pengeboran yang diambil langsung dari sumbernya; (b) barang kebutuhan pokok yang sangat dibutuhkan oleh rakyat banyak; (c) makanan dan minuman yang disajikan di hotel, restoran, rumah makan, warung dan sejenisnya, meliputi makanan dan minuman baik yang dikonsumsi di tempat maupun tidak, termasuk makanan dan minuman yang diserahkan oleh usaha jasa boga atau katering; dan (d) uang, emas batangan dan surat berharga.

Kemudian pada ayat (3) pasal ini disebutkan jenis jasa yang tidak dikenai Pajak Pertambahan Nilai, 
yaitu: (a) jasa pelayanan kesehatan medis; (b) jasa pelayanan sosial; (c) jasa pengiriman surat dengan perangko; (d) jasa keuangan; (e) jasa asuransi; (f) jasa keagamaan; (g) jasa pendidikan; (h) jasa kesenian dan hiburan; (i) jasa penyiaran yang tidak bersifat iklan; (j) jasa angkutan umum di darat dan di air serta jasa angkutan udara dalam negeri yang menjadi bagian yang tidak terpisahkan dari jasa angkutan udara luar negeri; (k) jasa tenaga kerja; (l) jasa perhotelan; (m) jasa yang disediakan oleh pemerintah dalam rangka menjalankan pemerintahan secara umum; (n) jasa penyediaan tempat parkir; (o) jasa telepon umum dengan menggunakan uang logam yaitu jasa telepon umum dengan menggunakan uang logam; (p) jasa pengiriman uang dengan wesel pos; dan (q) jasa boga atau katering.

\section{PAJAK PERTAMBAHAN NILAI UNTUK JASA KEUANGAN PERBANKAN}

European Commission (1996) menggolongkan jasa keuangan menjadi 5 kategori utama, yaitu: (a) kegiatan mendepositokan dan pinjam-meminjam melalui bank serta operasi kartu kredit; (b) pembelian, penjualan dan penerbitan sekuritas keuangan: obligasi, saham, opsi, garansi, jaminan, mata uang asing, emas dan logam mulia; (c) asuransi berupa asuransi jiwa, asuransi properti dan asuransi kecelakaan; (d) pedagang perantara dan jasa keagenan lain untuk membeli dan menjual sekuritas keuangan, penanggung dan transaksi lain di mana agen bertindak sebagai prinsipal; (e) penasihat untuk membeli dan menjual sekuritas keuangan, penanggung dan transaksi lain di mana agen bertindak sebagai prinsipal, jasa manajemen dan pengolahan data serta jasa lainnya.

KPMG (2013) membagi 4 kategori jasa keuangan, yaitu: (a) jasa intermediasi keuangan, misalnya: deposito dan pinjaman; (b) jasa layanan yang memperoleh penghasilan berupa fee, misalnya: layanan elektronik perbankan, jasa agen, jasa penyelesaian, jasa penasihat dan konsultasi, jasa pengamanan, jasa manajemen aset; (c) jasa keuangan yang memperoleh penghasilan dari keuntungan, misalnya: perdagangan saham, obligasi, derivatif, mata uang asing; (d) jasa perdagangan komoditas umum, misalnya: perdagangan logam mulia.

Mengenai pengenaan Pajak Pertambahan Nilai untuk jasa keuangan, Merrill (2011) berpendapat bahwa kebanyakan negara dengan sistem Pajak Pertambahan Nilai memilih mengecualikan sejumlah jasa keuangan karena kesulitan untuk mengukur biaya keuangan implisit. Pendapat senada disampaikan oleh Schenk (2009) yang menyatakan sistem Pajak Pertambahan Nilai dengan faktur dikreditkan yang saat ini diimplementasikan di seluruh dunia tidak bisa dengan baik digunakan untuk menangani jasa keuangan, di mana nilai tambah dari jasa keuangan tersebut tertanam di dalam tingkat bunga. Untuk alasan ini, sistem Pajak Pertambahan Nilai mengecualikan jasa keuangan dan asuransi dari pengenaan Pajak Pertambahan Nilai. Poddar and English (1997) menyatakan jasa keuangan umumnya dikecualikan dari pengenaan Pajak Pertambahan Nilai karena ketidakmampuannya untuk mengidentifikasi dasar pajak yang layak, yang tersembunyi dalam keuntungan jasa keuangan. 
Zee (2004) menyatakan mayoritas lebih dari 120 negara dengan sistem Pajak Pertambahan Nilai mengecualikan jasa keuangan dari pengenaan Pajak Pertambahan Nilai. Negaranegara maju cenderung mengenakan Pajak Pertambahan Nilai untuk sedikit jasa keuangan yang diberikan dengan imbalan suatu biaya eksplisit, negaranegara berkembang cenderung tidak memasukkan jasa keuangan sebagai jasa yang dikenakan Pajak Pertambahan Nilai. Secara konsep, Pajak Pertambahan Nilai akan diaplikasikan pada beberapa fee atas jasa, tetapi untuk jasa keuangan sukar untuk mengidentifikasi jumlah yang akan dipajaki (Feria and Walpole, 2009).

European Commission (1996) menyatakan bahwa perlakuan mengenai jasa-jasa keuangan yang dikecualikan dan tidak dikecualikan pada negara-negara yang menganut sistem Pajak Pertambahan Nilai adalah sebagai berikut: (a) jasa-jasa yang di semua negara dikecualikan dari pengenaan Pajak Pertambahan Nilai: deposito dan pinjaman, asuransi jiwa, pembelian, penjualan dan penerbitan sekuritas keuangan selain logam mulia; (b) jasajasa yang di semua negara dapat dipungut Pajak Pertambahan Nilai: jasa penasihat, jasa manajemen dan jasa pengolahan data, transaksi yang berhubungan dengan mata uang, penyewaan safety deposit box, jasa penagihan hutang dan jasa-jasa khusus lain; (c) jasa-jasa yang dikecualikan di banyak negara, tetapi tidak di semua negara: asuransi properti, asuransi kecelakaan, pedagang perantara dan jasa keagenan lain, transaksi emas, manajemen investasi dan mutual fund.

Jasa keuangan yang diberikan oleh institusi keuangan perbankan pada dasarnya dapat dibedakan menja- di 2, yaitu jasa intermediasi keuangan dan jasa-jasa lain yang di luar jasa intermediasi. Jasa keuangan intermediasi diberikan oleh bank dalam bentuk menerima deposito/simpanan dan kemudian dana deposito/simpanan tersebut akan diberikan dalam bentuk pinjaman. Jasa lain-lain yang diberikan oleh bank bisa berupa jasa pembayaran rekening listrik, air dan telpon, jasa persewaan safety deposit box, jasa penasihat keuangan, jasa manajemen, jasa pengolahan data, jasa penagihan hutang dan jasa-jasa khusus lainnya.

Penghasilan yang diperoleh oleh bank dari pemberian jasa lain-lain biasanya berupa fee yang jumlahnya jelas secara eksplisit. Poddar and English (1997) menyatakan secara prinsip tidak ada kesukaran di dalam mengaplikasikan Pajak Pertambahan Nilai terhadap beban eksplisit yang diterima bank, seperti penghasilan sewa safe deposit box, fee untuk jasa trustee service, komisi sebagai pedagang perantara sekuritas keuangan dan beban yang dipungut untuk penerbitan travel cek. Besarnya Pajak Pertambahan Nilai yang akan dipungut dihitung dengan mengalikan jumlah eksplisit yang diterima dengan tarif Pajak Pertambahan Nilai. Jadi tidak ada kesukaran untuk menghitung dan membebani Pajak Pertambahan Nilai untuk transaksi pemberian jasa lainlain dari perbankan. Hal ini juga diungkapkan oleh Boadway and Keen (2003) yang menyatakan untuk jasa keuangan yang disediakan dan dibayar dengan dasar fee seperti jasa persewaan safe-keeping dan penasihat keuangan, tidak ada kesulitan khusus: Pajak Pertambahan Nilai dapat dibebankan dengan cara biasa. Kesulitan timbul untuk jasa-jasa keuangan yang penghasilannya diperoleh dari selisih antara 
penghasilan yang diperoleh dari peminjam dana dengan biaya yang dibayarkan kepada penyimpan dana. Masalahnya adalah tidak dapat mengidentifikasi nilai tambah yang ditimbulkan oleh jasa intermediasi tersebut.

Untuk pemberian jasa intermediasi keuangan, penghasilan dari bank diperoleh dari selisih bunga yang diterima dari nasabah peminjam dengan bunga yang dibayarkan kepada nasabah penyimpan uang ke bank. Jadi penghasilan bank dari transaksi jasa intermediasi keuangan bersifat implisit tidak ekplisit jumlahnya. Seperti dikatakan oleh Schenk (2009) nilai dari jasa intermediasi secara implisit adalah keuntungan antara bunga yang dibebankan kepada peminjam dengan bunga yang dibayar untuk dana yang dipinjamkan.

Pajak Pertambahan Nilai yang dipungut dapat dihitung dengan menggunakan 3 metode, yaitu: (a) addition method; (b) substraction method dan (c) invoice-credit method. Dari ketiga metode ini, yang paling banyak digunakan oleh hampir semua negara yang mengaplikasikan sistem Pajak Pertambahan Nilai adalah invoice-credit method. Penghasilan yang diterima bank dari jasa intermediasi dalam bentuk implisit sulit untuk dikenakan Pajak Pertambahan Nilai, bila menggunakan invoice-credit method. Penggunaan invoice-credit method membutuhkan nilai eksplisit dari suatu transaksi. Oleh karena itu akhirnya hampir seluruh negara yang menggunakan sistem Pajak Pertambahan Nilai mengecualikan penghasilan jasa intermediasi perbankan dari pengenaan Pajak Pertambahan Nilai.

Pengecualian pengenaan Pajak Pertambahan Nilai pada sektor jasa keuangan mempunyai dampak yang tidak baik bagi penerapan sistem Pajak Pertambahan Nilai. Le (2003) menyatakan pengecualian pada suatu tahapan akan mengeliminasi transaksi tersebut dari rantai produksi dan distribusi. Seperti yang dikatakan Zee (2004) karena rata-rata kurang lebih $1 / 4$ dari GDP di negara-negara maju berasal dari sektor keuangan, pengecualian sektor ini dari pengenaan Pajak Pertambahan Nilai dapat memberikan distorsi ekonomi yang signifikan. Poddar and English (1997) menyatakan meskipun pendekatan pengecualian diadopsi secara luas, ada masalah signifikan di dalam operasinya. Timbulnya tax cascading memunculkan distorsi ekonomi yang banyak sekali dan pengaruh negatif terhadap posisi daya saing dari institusi domestik di dalam pasar internasional. Feria and Walpole (2009) juga menyatakan perlakuan jasa keuangan untuk dikecualikan dari pengenaan Pajak Pertambahan Nilai memunculkan distorsi ekonomi dan legal yang signifikan. Merrill (2011) menyatakan bahwa pengecualian jasa keuangan dari pengenaan Pajak Pertambahan Nilai mengarahkan aturan Pajak Pertambahan Nilai menjadi tidak sederhana dan secara ekonomi tidak netral.

Walaupun hampir semua negara yang menggunakan sistem Pajak Pertambahan Nilai mengecualikan jasa intermediasi keuangan dari pengenaan Pajak Pertambahan Nilai, namun ada beberapa negara yang tetap mengenakan Pajak Pertambahan Nilai terhadap jasa intermediasi keuangan. Boadway and Keen (2003) menyatakan beberapa negara (terutama Israel) memajaki nilai tambah dari jasa keuangan dengan addition method: yaitu membebankan Pajak Pertambahan Nilai secara langsung dari jumlah gaji, upah dan 
laba. Sebuah alternatif potensial diberikan melalui penggunaan substraction method (seperti di salah satu usulan yang diusulkan di Kanada) di mana Pajak Pertambahan Nilai hanya dibebankan dari kelebihan output perusahaan di atas input perusahaan.

Meskipun masih memungkinkan untuk menggunakan addition method dan substraction method untuk membebankan Pajak Pertambahan Nilai pada jasa intermediasi keuangan, tetapi karena pengenaan Pajak Pertambahan Nilai pada sektor-sektor di luar jasa keuangan intermediasi menggunakan invoice-credit method, maka implementasi addition method dan atau substraction method bersamaan dengan invoice-credit method pada sistem Pajak Pertambahan Nilai menjadi tidak mungkin.

Secara konseptual pengenaan Pajak Pertambahan Nilai pada jasa intermediasi keuangan dengan menggunakan invoice-credit method sulit untuk diimplementasikan. Karenanya selama ini hampir semua negara yang menggunakan sistem Pajak Pertambahan Nilai mengecualikan jasa intermediasi keuangan dari pengenaan Pajak Pertambahan Nilai. Pengecualian pengenaan Pajak Pertambahan Nilai untuk jasa intermediasi keuangan yang diberikan oleh pihak perbankan memberikan banyak dampak yang negatif terhadap implementasi sistem Pajak Pertambahan Nilai. Di samping akan mengurangi jumlah penerimaan dari sektor pajak, pengecualian ini akan berdampak terjadinya distorsi baik dari sudut ekonomi maupun dari sudut legal.

Pengecualian pengenaan Pajak Pertambahan Nilai terhadap jasa intermediasi keuangan mengandung unsur ketidakadilan. Di satu sisi adanya pe- ngecualian akan menyebabkan kontribusi sektor jasa keuangan terhadap penerimaan negara dari sektor pajak, khususnya Pajak Pertambahan Nilai menjadi minim sekali. Di lain sisi negara akan menggunakan seluruh penerimaan yang didapat untuk membiayai semua sektor tanpa kecuali, termasuk sektor keuangan.

Krisis keuangan yang terjadi dalam tahun 2008 menyebabkan banyak negara harus mengeluarkan sejumlah dana yang besar untuk keperluan bailout lembaga-lembaga keuangan bank dan non bank. Langkah tersebut harus dilakukan agar krisis keuangan yang terjadi tidak menyebabkan terjadinya rush dan hilangnya kepercayaan masyarakat terhadap lembaga perbankan. Keen (2011) mengatakan tekanan dan kegagalan potensial dari institusi keuangan secara sistemik selama krisis akan menghadapkan pemerintah pada satu masalah. Masalah yang timbul adalah membiarkan saja lembaga keuangan tersebut menghadapi kesulitan yang terjadi atau menyelamatkan lembaga keuangan dari kebangkrutan dengan memberikan injeksi dana dalam bentuk bailout yang jumlahnya besar. Jika pemerintah melakukan tindakan penyelamatan lembaga keuangan tersebut, maka pemerintah harus mengeluarkan dana yang besar yang mestinya dapat digunakan untuk membiayai kepentingan publik lain yang lebih penting. Tetapi jika langkah penyelamatan tidak dilakukan dikhawatirkan kebangkrutan dan keambrukan lembaga keuangan tersebut akan berefek domino pada sektor-sektor lain yang akan memberi pengaruh negatif pada ekonomi secara nasional.

Berlatar belakang krisis keuangan pada tahun 2008 ini, banyak 
negara mulai memikirkan kembali perlakuan pengecualian pengenaan Pajak Pertambahan Nilai untuk jasa keuangan, khususnya jasa intermediasi keuangan. Ada arus kuat untuk memberlakukan pemungutan Pajak Pertambahan Nilai atas transaksi jasa intermediasi keuangan. Beberapa metode pengenaan Pajak Pertambahan Nilai untuk jasa intermediasi keuangan yang pernah diusulkan oleh beberapa ahli mulai dipertimbangkan untuk digunakan. Beberapa metode tersebut antara lain adalah:

\section{(a) Addition Method}

Pada metode ini Pajak Pertambahan Nilai akan dikenakan terhadap nilai yang ditambahkan pada suatu jasa intermediasi keuangan yang disediakan oleh suatu institusi keuangan. Dasar Pengenaan Pajak-nya (DPP) adalah keseluruhan biaya yang dikeluarkan terkait dengan pemberian jasa intermediasi keuangan ditambah keuntungan. Jadi misalkan suatu bank memberikan bunga sebesar $10 \%$ untuk nasabah yang menyimpan uangnya dalam bentuk deposito di bank tersebut. Kemudian dana deposito tersebut akan dipinjamkan ke nasabah lain yang membutuhkan dana dengan bunga sebesar 15\%. Apabila berhubungan dengan pelaksanaan kegiatan pemberian jasa intermediasi keuangan ini bank mengeluarkan biaya gaji, upah, sewa gedung, alat-alat tulis, dan biaya lain-lainnya sebesar Rp. 5.000.000.000,- serta bank menginginkan keuntungan sebesar Rp. 2.500.000.000,-, maka besarnya Pajak Pertambahan Nilai yang akan diperhitungkan untuk pemberian jasa intermediasi keuangan yang diberikan oleh bank adalah sebesar $=$ tarif Pajak Pertambahan Nilai x (Rp. 5.000.000.000,- + Rp. 2.500.000.000,-). Bila tarif Pajak Pertambahan Nilai yang diberlakukan adalah 10\%, maka besarnya Pajak Pertambahan Nilai adalah sebesar Rp. 750.000.000,- (10\% x Rp. 7.500.000.000,-). Menurut European Commission (1996) ada beberapa kesukaran penerapan Addition Method untuk mengenakan Pajak Pertambahan Nilai pada jasa intermediasi keuangan, yaitu: incompatibility dengan metode credit-invoice untuk transaksi non keuangan, termasuk origin basis, sehingga tidak memperhitungkan nilai yang diperhitungkan pada tahapan sebelumnya dalam rantai produksi dan distribusi serta adanya ketidaksesuaian dengan perhitungan pajak penghasilan untuk keuntungan.

(b) Subtraction Method

Pajak Pertambahan Nilai akan dikenakan terhadap selisih nilai output dan nilai input. Jadi misalkan suatu bank memberikan bunga sebesar $1 \%$ per-bulan untuk nasabah yang menyimpan uang dalam bentuk deposito di bank dan mengenakan bunga sebesar $2 \%$ per-bulan bagi nasabah yang ingin meminjam uang dari bank tersebut. Jika dalam satu bulan diperoleh simpanan deposito sebesar Rp. 100.000.000.000,- dan jumlah pinjaman yang diberikan pada bulan tersebut juga sama jumlahnya sebesar Rp. 100.000.000.000,-, maka berarti nilai input atas jasa intermediasi keuangan yang diberikan pada bulan tersebut adalah sebesar Rp. 1.000.000.000,(1\% x Rp. 100.000.000.000,-) dan nilai output atas jasa intermediasi 
keuangan yang diberikan pada bulan tersebut adalah sebesar Rp. 2.000.000.000,- $(2 \%$ x Rp. 100.000.000.000,-). Besarnya Pajak Pertambahan Nilai yang dikenakan atas transaksi ini sebesar Rp. 100.000.000,-, yaitu tarif $10 \%$ dikalikan dengan selisih nilai output (Rp. 2.000.000.000,-) dengan nilai input (Rp. 1.000.000.000,-).

(c) Cash Flow Method

Menurut Poddar and English (1997) esensi dari Cash Flow Method adalah bahwa metode ini memperlakukan arus kas dari transaksi keuangan dengan cara yang sama seperti arus kas dari transaksi non keuangan. Arus kas masuk dari transaksi keuangan akan diperlakukan seperti transaksi penjualan jasa yang akan dikenakan Pajak Pertambahan Nilai. Dalam hal ini akan timbul Pajak Pertambahan Nilai Keluaran yang akan dapat diperhitungkan dengan Pajak Pertambahan Nilai Masukan yang dapat dikreditkan. Sedangkan arus kas ke luar yang berasal dari transaksi keuangan akan diperlakukan sebagai pembelian jasa yang akan dikenakan Pajak Pertambahan Nilai Masukan yang dapat dikreditkan dengan Pajak Pertambahan Nilai Keluaran. Timbulnya arus kas masuk dan arus kas ke luar yang disebabkan transaksi yang berhubungan dengan ekuitas pemilik, misalkan arus kas masuk dari tambahan modal pemilik atau arus kas ke luar karena pembagian deviden kepada pemilik tidak termasuk pengertian arus kas masuk dan arus kas ke luar yang menjadi Dasar Pengenaan Pajak (DPP) Pajak Pertambahan Nilai dengan metode Cash Flow Method. Demikian pula arus kas masuk berkaitan dengan perolehan penghasilan di luar jasa intermediasi keuangan yang telah dikenakan Pajak Pertambahan Nilai dengan credit-invoice method dan arus kas ke luar untuk pengeluaran rutin tidak termasuk Dasar Pengenaan Pajak Pertambahan Nilai dengan metode ini. Pengenaan Pajak Pertambahan Nilai dengan tarif $0 \%$ akan dikenakan apabila transaksi jasa intermediasi keuangan melibatkan pihak-pihak yang berada di luar daerah pabean. Berikut ini diberikan contoh untuk menghitung Pajak Pertambahan Nilai dengan menggunakan Cash Flow Method. Misalkan bank menerima deposito dari nasabah dan memberikan bunga atas deposito dengan tarif bunga sebesar $8 \%$ pertahun serta memberikan pinjaman kepada pihak peminjam dengan tarif bunga pinjaman sebesar $15 \%$ per-tahun. Diketahui pula bahwa tarif bunga yang ditetapkan pemerintah untuk hutang jangka pendeknya $12 \%$ per-tahun, jumlah dana deposito yang diterima dan dana yang dipinjamkan oleh bank sebesar Rp. 100.000.000,- serta tarif Pajak Pertambahan Nilai sebesar $10 \%$. Diasumsikan bahwa pinjaman dan deposito diberikan dan diterima untuk jangka waktu 1 tahun, mulai tanggal 1 Januari sampai dengan 31 Desember serta pihak yang mendepositokan dan pihak yang meminjam uang ke dan dari bank bukan Pengusaha Kena Pajak (PKP). Perhitungan Pajak Pertambahan Nilai dengan Cash Flow Method dari data-data tersebut di atas dapat dilihat seperti pada Tabel 1 di bawah ini. 
Tabel 1

Perhitungan Pajak Pertambahan Nilai dengan Cash Flow Method Pihak yang Mendepositokan dan Meminjam Bukan PKP

\begin{tabular}{|c|c|c|c|}
\hline Keterangan & $\begin{array}{c}\text { Arus Kas } \\
\text { Masuk Bank } \\
\text { (Rp.) }\end{array}$ & $\begin{array}{c}\text { Arus Kas } \\
\text { Ke luar Bank } \\
\text { (Rp.) }\end{array}$ & $\begin{array}{l}\text { PPN Keluaran/ } \\
\text { (PPN Masukan) } \\
\text { (Rp.) }\end{array}$ \\
\hline \multicolumn{4}{|l|}{$\begin{array}{l}\text { Periode 1: saat menerima } \\
\text { deposito dan memberikan } \\
\text { pinjaman }\end{array}$} \\
\hline $\begin{array}{l}\text { Pada saat dana deposito } \\
\text { diterima }\end{array}$ & 100.000 .000 & & 10.000 .000 \\
\hline Pada saat dana dipinjamkan & & $(100.000 .000)$ & $(10.000 .000)$ \\
\hline $\begin{array}{l}\text { Jumlah yang dilaporkan pada } \\
\text { periode } 1\end{array}$ & 100.000 .000 & $(100.000 .000)$ & 0 \\
\hline \multicolumn{4}{|l|}{$\begin{array}{l}\text { Periode 2: saat menerima } \\
\text { kembali pinjaman dan } \\
\text { membayar deposito }\end{array}$} \\
\hline $\begin{array}{l}\text { Pada saat dana pinjaman } \\
\text { diterima kembali: } \\
\text { - Penerimaan dana pinjaman } \\
\text { - Penerimaan bunga pinjaman }\end{array}$ & $\begin{array}{r}100.000 .000 \\
15.000 .000 \\
\end{array}$ & & $\begin{array}{r}10.000 .000 \\
1.500 .000 \\
\end{array}$ \\
\hline $\begin{array}{l}\text { Pada saat deposito dicairkan: } \\
\text { - Pengembalian dana deposito } \\
\text { - Pembayaran bunga deposito }\end{array}$ & & $\begin{array}{r}(100.000 .000) \\
(8.000 .000)\end{array}$ & $\begin{array}{r}(10.000 .000) \\
(800.000) \\
\end{array}$ \\
\hline $\begin{array}{l}\text { Jumlah yang dilaporkan pada } \\
\text { periode } 2\end{array}$ & 115.000 .000 & $(108.000 .000)$ & 700.000 \\
\hline $\begin{array}{l}\text { Jumlah keseluruhan dari } \\
\text { transaksi tersebut }\end{array}$ & 215.000 .000 & $(208.000 .000)$ & 700.000 \\
\hline
\end{tabular}

Sumber: European Commission (1996) serta Poddar and English (1997) setelah dimodifikasi

Dari Tabel 1 di atas nampak bahwa pada saat periode 1, yaitu saat penerimaan deposito dan pemberian pinjaman oleh bank jumlah PPN Keluaran dan PPN Masukan sama besarnya, artinya tidak ada PPN yang disetorkan kepada pemerintah. Hal ini disebabkan karena jumlah arus kas masuk dan arus kas ke luar pada periode tersebut sama besarnya, artinya arus kas bersih sama dengan 0. Pada metode ini arus kas bersih merupakan Dasar Pengenaan Pajak (DPP)
Pajak Pertambahan Nilai. Apabila arus kas bersihnya sama dengan 0 , artinya DPP sama dengan 0, maka Pajak Pertambahan Nilai yang dibebankan juga sama dengan 0 . Kemudian pada periode 2, yaitu saat penerimaan kembali pinjaman beserta bunganya dan pembayaran deposito beserta bunganya, ada arus kas masuk sebesar Rp. 115.000.000,- yang berasal dari penerimaan pengembalian pinjaman sebesar Rp. 100.000.000,- dan penerimaan bunga dari pinjaman 
sebesar Rp. 15.000.000,-. Pada periode 2 ini juga ada arus kas ke luar sebesar Rp. 108.000.000,untuk pembayaran pengembalian deposito dan pembayaran bunga deposito sebesar Rp. 8.000.000,-Jadi pada periode 2 ini ada arus kas masuk sebesar Rp. 115.000.000,dan ada arus kas ke luar sebesar Rp. 108.000.000,- atau dapat dikatakan ada arus kas masuk bersih sebesar Rp. 7.000.000,-Karena ada arus kas masuk bersih sebesar Rp. 7.000.000,-, maka akan ada Pajak Pertambahan Nilai yang dipungut yaitu sebesar Rp. 700.000,- (10\% x Rp. 7.000.000,-). Pajak Pertambahan Nilai ini bagi bank merupakan Pajak Pertambahan Nilai Keluaran yang harus disetorkan kepada pemerintah. Secara keseluruhan apabila periode 1 dan periode 2 digabung, maka akan ada arus kas masuk sebesar Rp. 215.000.000,- serta ada arus kas ke luar sebesar Rp. 208.000.000,-. Jadi ada selisih sebesar Rp. 7.000.000,- yang merupakan arus kas masuk bersih. Secara keseluruhan jumlah Pajak Pertambahan Nilai yang akan dibayar adalah sebesar Rp. 700.000,- (10\% x Rp. 7.000.000,-). Jika yang mendepositokan dan meminjam ke dan dari bank adalah bukan PKP, maka pemungutan dan penyetoran Pajak Pertambahan Nilai akan dilakukan oleh pihak bank. Bagi pihak yang mendepositokan dan pihak yang meminjam tidak ada kewajiban untuk melakukan pemungutan Pajak Pertambahan Nilai Keluaran dan tidak dapat mengkreditkan Pajak Pertambahan Nilai Masukan. Jika pihak yang mendepositokan dan pihak yang meminjam salah satunya atau keduanya merupakan Pengusaha Kena Pajak (PKP), maka bagi salah satu pihak atau kedua pihak yang merupakan Pengusaha Kena Pajak (PKP) akan mempunyai dampak terhadap kewajiban Pajak Pertambahan Nilainya. Sedangkan bila pihak yang mendepositokan dan pihak yang meminjam salah satunya atau keduanya tidak bertempat tinggal atau tidak bertempat kedudukan di Indonesia, maka pengenaan Pajak Pertambahan Nilai bagi salah satu pihak atau kedua pihak yang tidak bertempat tinggal atau tidak bertempat kedudukan di Indonesia akan dikenakan tarif $0 \%$.

(d) Cash Flow Method With Tax Calculation Account (TCA)

Metode Cash Flow Method With Tax Calculation Account merupakan penyempurnaan dari Cash Flow Method yang murni. Dengan metode ini akan dibentuk suatu rekening guna menampung Pajak Pertambahan Nilai untuk deposito dan pinjaman. Jadi selama periode proses penerimaan deposito dan pemberian pinjaman masih berjalan tidak ada pembayaran Pajak Pertambahan Nilai Keluaran yang masih terutang dan klaim pengkreditan Pajak Pertambahan Nilai Masukan. Semua Pajak Pertambahan Nilai Keluaran yang masih terutang dan klaim pengkreditan Pajak Pertambahan Nilai Masukan akan dicatat dalam Rekening Perhitungan Pajak (TCA) yang pada saat periode akhir proses penerimaan deposito dan pemberian pinjaman (saat transaksi pembalikan) jumlah yang ada pada Rekening Perhitungan Pajak yang 
menunjukkan jumlah hutang Pajak Pertambahan Nilai harus disetorkan kepada pemerintah. Berikut contoh penggunaan metode ini dengan menggunakan data-data dan asumsi dari contoh sebelumnya seperti terlihat pada Tabel 2 dan Tabel 3. Pada Tabel 2 ditampilkan perhitungan pajak untuk transaksi pinjaman. Pada periode 1 , ada $\mathrm{Pa}-$ jak Pertambahan Nilai Masukan sebesar Rp. 11.200.000,- yang terdiri dari Rp. 10.000.000,- berasal dari perkalian arus kas ke luar sebesar Rp. 100.000.000,- dengan tarif pajak dan Rp. 1.200.000,- berasal dari indeks perhitungan pajak yaitu hasil perkalian tarif bunga pemerintah dan besarnya pinjaman serta tarif pajak. Kemudian pada periode 2, ada arus kas masuk sebesar Rp. 115.000.000,- berasal dari penerimaan pengembalian pinjaman ditambah bunga. Dalam hal ini ada Pajak Pertambahan Nilai Keluaran Rp. 11.5000.000,-. Pajak Pertambahan Nilai Keluaran ini dikurangi dengan Pajak Pertambahan Nilai Masukan akan diperoleh saldo Pajak Pertambahan Nilai Keluaran sebesar Rp. 300.000,pada Rekening Perhitungan Pajak (TCA). Tabel 3 menunjukkan perhitungan pajak untuk transaksi penerimaan deposito. Pada periode 1 ada Pajak Pertambahan Nilai Keluaran sebesar Rp. 11.200.000,berasal dari Pajak Pertambahan Nilai Keluaran arus kas masuk penerimaan deposito dan dari indeks perhitungan pajak. Pada periode 2 ada Pajak Pertambahan Nilai Masukan sebesar Rp. 10.800.000,- berasal dari arus kas ke luar untuk pembayaran kembali deposito beserta bunganya sebesar Rp. 108.000.000,-. Pajak Pertambahan Nilai Keluaran setelah dikurangi Pajak Pertambahan Nilai Masukan diperoleh saldo Pajak Pertambahan Nilai Keluaran sebesar Rp. 400.000,- pada Rekening Perhitungan Pajak (TCA).

Tabel 2

Perhitungan Pajak Pertambahan Nilai dengan Cash Flow Method With TCA TCA untuk Pinjaman yang Diberikan Bank

\begin{tabular}{|l|c|c|}
\hline \multicolumn{1}{|c|}{ Keterangan } & $\begin{array}{c}\text { Arus Kas } \\
\text { Masuk/(Arus } \\
\text { Kas Ke Luar) } \\
\text { (Rp.) }\end{array}$ & $\begin{array}{c}\text { Rekening } \\
\text { Perhitungan } \\
\text { Pajak (TCA) } \\
\text { (Rp.) }\end{array}$ \\
\hline Periode 1: saat pemberian pinjaman & & $(10.000 .000)$ \\
\hline Pemberian pinjaman & $(100.000 .000)$ & $(1.200 .000)$ \\
\hline TCA indexing & - & \\
\hline $\begin{array}{l}\text { Periode 2: saat penerimaan kembali } \\
\text { pinjaman }\end{array}$ & & 10.000 .000 \\
\hline Penerimaan kembali dana pinjaman & 100.000 .000 & 1.500 .000 \\
\hline Penerimaan bunga pinjaman & 15.000 .000 & - \\
\hline Nilai penutupan pinjaman & - & 300.000 \\
\hline Pajak Pertambahan Nilai Bersih yang masih harus dibayar & \\
\hline
\end{tabular}

Sumber: Poddar and English (1997) setelah dimodifikasi 
Tabel 3

Perhitungan Pajak Pertambahan Nilai dengan Cash Flow Method With TCA TCA untuk Deposito yang Diterima Bank

\begin{tabular}{|l|c|c|}
\hline \multicolumn{1}{|c|}{ Keterangan } & $\begin{array}{c}\text { Arus Kas } \\
\text { Masuk/(Arus } \\
\text { Kas Ke Luar) } \\
(\mathrm{Rp} .)\end{array}$ & $\begin{array}{c}\text { Rekening } \\
\text { Perhitungan } \\
\text { Pajak (TCA) } \\
\text { (Rp.) }\end{array}$ \\
\hline Periode 1: saat penerimaan deposito & & 10.000 .000 \\
\hline Penerimaan deposito & 100.000 .000 & 1.200 .000 \\
\hline TCA indexing & - & \\
\hline $\begin{array}{l}\text { Periode 2: saat pembayaran kembali } \\
\text { deposito }\end{array}$ & & $(10.000 .000)$ \\
\hline Pembayaran dana deposito & $(100.000 .000)$ & $(800.000)$ \\
\hline Pembayaran bunga deposito & - & - \\
\hline Nilai penutupan pinjaman & $(8.000 .000)$ & 400.000 \\
\hline Pajak Pertambahan Nilai Bersih yang masih harus dibayar & \\
\hline
\end{tabular}

Sumber: Poddar and English (1997) setelah dimodifikasi

(e) Reverse Charging Method

Metode ini beranggapan bahwa pemberian pinjaman oleh bank sama dengan transaksi penyerahan yang dikenakan Pajak Pertambahan Nilai dan bank harus memungut Pajak Pertambahan Nilai Keluaran. Sebaliknya pada saat bank menerima dana deposito dianggap bahwa bank menerima penyerahan yang dikenakan Pajak Pertambahan Nilai dan bank harus membayar Pajak Pertambahan Nilai Masukan yang dapat dikreditkan. Jadi pada transaksi pemberian pinjaman, bank sebagai Pengusaha Kena Pajak harus membuat faktur pajak untuk memungut Pajak Pertambahan Nilai Keluaran dari pihak peminjam dan bagi pihak peminjam Faktur Pajak Masukan ini dapat dikreditkan sebagai Pajak Pertambahan Nilai Masukan. Sedangkan untuk faktur pajak yang harus diterbitkan pada saat bank menerima dana deposito, seharusnya faktur pajak diterbitkan oleh pihak yang mendepositokan dananya di bank sebagai Faktur Pajak Keluaran. Namun karena jumlah pihak yang mendepositokan dana ke bank sangat banyak dan sebagian besar bukan Pengusaha Kena Pajak, maka pada metode ini faktur pajak tersebut juga diterbitkan oleh bank. Jadi dalam hal ini bank akan menerbitkan faktur pajak untuk transaksi penerimaan deposito di mana bank sebagai pihak yang menerima penyerahan dan faktur pajak untuk transaksi pemberian pinjaman di mana bank sebagai pihak yang melakukan penyerahan. Faktur Pajak Pertambahan Nilai Masukan yang diterbitkan pada waktu menerima deposito akan dikreditkan dengan Faktur Pajak Pertambahan Nilai Keluaran yang dibuat pada saat penerimaan pinjaman. Berikut ini contoh penerapan metode ini menggunakan data-data dan asumsi dari contoh sebelumnya seperti terlihat pada Tabel 4. 
Tabel 4

Perlakuan Pajak Pertambahan Nilai atas Deposito dan Pinjaman Dari dan Kepada Pihak Dalam Negeri dengan Reverse Charging Method

\begin{tabular}{|c|c|c|c|}
\hline Keterangan & $\begin{array}{c}\text { Pihak Yang } \\
\text { Mendepositokan (D) } \\
\end{array}$ & Bank (B) & $\begin{array}{c}\text { Pihak Peminjam } \\
(\mathbf{P})\end{array}$ \\
\hline \multicolumn{4}{|c|}{ D dan P adalah Konsumen Akhir atau D adalah PKP Bisnis dan $P$ adalah Konsumen Akhir } \\
\hline $\begin{array}{l}\text { B menerbitkan faktur pajak } \\
\text { dan memungut PPN Ke- } \\
\text { luaran atas transaksi } \\
\text { pemberi pinjaman kepada P. }\end{array}$ & - & $\begin{array}{l}\text { Memungut PPN Ke- } \\
\text { luaran dari P dengan } \\
\text { menerbitkan faktur } \\
\text { pajak sebesar Rp. } \\
1.500 .000,-.\end{array}$ & $\begin{array}{l}\text { Membayar PPN Ma- } \\
\text { sukan sebesar Rp. } \\
1.500 .000,- \text { kepada B } \\
\text { dan tidak ada kewa- } \\
\text { jiban melaporkan PPN. }\end{array}$ \\
\hline $\begin{array}{l}\text { B berfungsi sebagai peng- } \\
\text { ganti dari D melakukan } \\
\text { pemungutan PPN atas tran- } \\
\text { saksi penerimaan deposito } \\
\text { dari D. }\end{array}$ & $\begin{array}{l}\text { Tidak ada kewajiban } \\
\text { menyetor dan atau } \\
\text { melaporkan PPN. }\end{array}$ & $\begin{array}{l}\text { Ada PPN reverse } \\
\text { charge sebesar Rp. } \\
800.000,- \text { dan meng- } \\
\text { kreditkannya sebagai } \\
\text { PPN Masukan. }\end{array}$ & - \\
\hline Pembayaran/Beban PPN. & $\begin{array}{l}\text { Menyetor PPN kepa- } \\
\text { da pemerintah, tapi } \\
\text { tidak membayarnya } \\
\text { langsung. Tidak me- } \\
\text { nanggung beban PPN }\end{array}$ & $\begin{array}{l}\text { Menyetor PPN sebe- } \\
\text { sar Rp. } 1.500 .000,- \\
\text { kepada pemerintah. } \\
\text { Tidak menanggung } \\
\text { beban PPN. }\end{array}$ & $\begin{array}{l}\text { Menyetor PPN kepada } \\
\text { pemerintah, tapi tidak } \\
\text { membayarnya lang- } \\
\text { sung. Menanggung be- } \\
\text { ban PPN atas deposito } \\
\text { dari D dan laba dari B. }\end{array}$ \\
\hline \multicolumn{4}{|c|}{ D adalah Konsumen Akhir dan $P$ adalah PKP Bisnis atau D dan $P$ adalah PKP bisnis } \\
\hline $\begin{array}{l}\text { B menerbitkan faktur pajak } \\
\text { dan memungut PPN Ke- } \\
\text { luaran atas transaksi } \\
\text { pemberi pinjaman kepada P. }\end{array}$ & 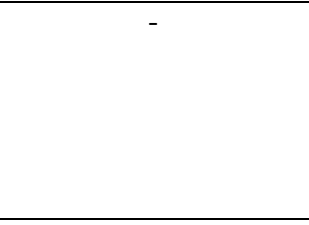 & $\begin{array}{l}\text { Memungut PPN Ke- } \\
\text { luaran dari P dengan } \\
\text { menerbitkan faktur } \\
\text { pajak sebesar Rp. } \\
1.500 .000,-.\end{array}$ & $\begin{array}{l}\text { Membayar PPN Ma- } \\
\text { sukan sebesar Rp. } \\
1.500 .000,- \text { kepada B. } \\
\text { Menerima faktur pajak } \\
\text { dari B dan mengkredit- } \\
\text { kan PPN Masukan. }\end{array}$ \\
\hline $\begin{array}{l}\text { B berfungsi sebagai peng- } \\
\text { ganti dari D melakukan } \\
\text { pemungutan PPN atas tran- } \\
\text { saksi penerimaan deposito } \\
\text { dari D. }\end{array}$ & $\begin{array}{l}\text { Tidak ada kewajiban } \\
\text { menyetor dan atau } \\
\text { melaporkan PPN. }\end{array}$ & $\begin{array}{l}\text { Ada PPN reverse } \\
\text { charge sebesar Rp. } \\
800.000,- \text { dan meng- } \\
\text { kreditkannya sebagai } \\
\text { PPN Masukan. }\end{array}$ & - \\
\hline Pembayaran/Beban PPN. & $\begin{array}{l}\text { Menyetor PPN kepa- } \\
\text { da pemerintah, tapi } \\
\text { tidak membayarnya } \\
\text { langsung. Tidak me- } \\
\text { nanggung beban PPN }\end{array}$ & $\begin{array}{l}\text { Menyetor PPN sebe- } \\
\text { sar Rp. } 1.500 .000,- \\
\text { kepada pemerintah. } \\
\text { Tidak menanggung } \\
\text { beban PPN. }\end{array}$ & $\begin{array}{l}\text { Menyetor PPN kepada } \\
\text { pemerintah, tapi tidak } \\
\text { membayarnya langsung. } \\
\text { Tidak menanggung be- } \\
\text { ban PPN. }\end{array}$ \\
\hline
\end{tabular}

Sumber: Zee (2004) setelah dimodifikasi

Dari Tabel 4 di atas, nampak kondisi yang sama akan terjadi pada bank, pihak yang mendepositokan dan pihak yang meminjam, bila pihak yang mendepositokan dan pihak yang meminjam konsumen akhir atau jika pihak yang mendepositokan adalah PKP bisnis dan pihak yang meminjam adalah konsumen akhir. Demikian pula kondisi yang sama akan terjadi pada bank, pihak yang mendepositokan dan pihak yang meminjam, bila pihak yang mendepositokan dan pihak yang meminjam adalah PKP bisnis atau jika pihak yang mendepositokan adalah konsumen akhir dan pihak yang meminjam adalah PKP bisnis. Sedangkan bila transaksi melibatkan pihak yang tidak bertempat tinggal atau tidak bertempat kedudukan di Indonesia, maka kondisi pada pihak yang mendepositokan tidak ada perubahan. Untuk bank, jika pihak yang meminjam adalah pihak yang tidak bertempat tinggal atau tidak bertempat kedudukan di Indonesia, 
maka bank akan memungut Pajak Pertambahan Nilai dengan tarif $0 \%$ atas pemberian pinjaman dan bila pihak yang meminjam adalah pihak yang bertempat tinggal atau bertempat kedudukan di Indonesia, maka bank akan memungut Pajak Pertambahan Nilai dengan tarif normal. Untuk pihak yang meminjam, jika bertempat tinggal atau bertempat kedudukan di Indonesia, maka akan membayar Pajak Pertambahan Nilai kepada bank dengan tarif normal atas pemberian pinjaman. Kemudian jika pihak yang meminjam adalah PKP bisnis, maka akan menerima faktur pajak dari bank dan mengkreditkan Faktur Pajak Pertambahan Nilai Masukan yang sudah dibayar kepada bank. Tetapi bila pihak yang meminjam bukan PKP bisnis, maka tidak ada kewajiban pajak lainnya. Jika pihak yang meminjam PKP bisnis, maka pihak yang meminjam tidak menanggung beban Pajak Pertambahan Nilai, tetapi jika pihak yang meminjam bukan PKP bisnis, maka pihak yang meminjam menanggung beban Pajak Pertambahan Nilai atas deposito dari pihak yang mendepositokan dan Pajak Pertambahan Nilai atas keuntungan dari bank.

(f) Modified Reverse Charging Method

Deposito yang diterima oleh bank dari pihak yang mendepositokan pada umumnya tidak semuanya langsung dipinjamkan kepada pihak peminjam. Dengan metode ini transaksi penerimaan deposito dan transaksi pemberian kredit akan dicatat dalam suatu rekening tertentu yang dinamakan franking account (Zee, 2004). Jumlah sisa dana tersedia yang diperoleh dari pihak yang mendepositokan dan belum dipinjamkan kepada pihak yang meminjam akan nampak sebagai saldo dari franking account. Menurut Zee (2004) rekening ini akan menunjukkan 3 saldo, yaitu: (1) kumulatif saldo deposito yang belum dipinjamkan; (2) kumulatif saldo reverse charges yang belum diklaim dari saldo deposito yang belum dipinjamkan; (3) reverse charges per unit dari deposito yang belum dipinjamkan. Semua saldo ini akan diperbarui setiap ada transaksi penerimaan deposito dan pemberian pinjaman dengan melakukan pengkreditan dan pendebetan. Untuk memperjelas penggunaan metode ini akan diberikan contoh penerapannya dengan menggunakan data-data berikut ini. Misalkan ada 3 transaksi penerimaan deposito dan 3 transaksi pemberian pinjaman secara berurutan sebagai berikut: (1) penerimaan deposito sebesar Rp. 1.000,- dengan bunga $8 \%$; (2) penerimaan deposito sebesar Rp. 3.000,- dengan bunga 10\%; (3) pemberian pinjaman sebesar Rp. 2.000 ,- dengan bunga $18 \%$; (4) penerimaan deposito sebesar Rp. 2.000 ,- dengan bunga 6\%; (5) pemberian pinjaman sebesar Rp. 1.000 ,- dengan bunga 14\%; (6) pemberian pinjaman sebesar Rp. 3.000,- dengan bunga 16\%. Tarif Pajak Pertambahan Nilai diasumsikan sebesar 10\%. Perhitungan Pajak Pertambahan Nilai dengan menggunakan metode ini seperti terlihat pada Tabel 5 . 
Tabel 5

Perhitungan Pajak Pertambahan Nilai dengan Menggunakan Modified Reverse Charging Method

\begin{tabular}{|c|c|c|c|c|c|c|c|c|c|c|c|}
\hline \multirow[b]{2}{*}{ No. } & \multicolumn{3}{|c|}{ Deposits } & \multicolumn{5}{|c|}{ Loans } & \multicolumn{3}{|c|}{ Franking Account } \\
\hline & $\begin{array}{l}\text { Principal } \\
\text { (Rp.) }\end{array}$ & $\begin{array}{c}\text { Interest } \\
\text { Rate }(\%)\end{array}$ & $\begin{array}{c}\text { Reverse } \\
\text { Charges } \\
\text { (Rp.) }\end{array}$ & $\begin{array}{l}\text { Principal } \\
\text { (Rp.) }\end{array}$ & $\begin{array}{l}\text { Interest } \\
\text { Rate (\%) }\end{array}$ & $\begin{array}{c}\text { Notional } \\
\text { VAT } \\
\text { (Rp.) }\end{array}$ & $\begin{array}{c}\text { VAT } \\
\text { Credit } \\
\text { From } \\
\text { Franking } \\
\text { Account } \\
\text { (Rp.) }\end{array}$ & $\begin{array}{l}\text { Net VAT } \\
\text { Paid By } \\
\text { Borrowers } \\
\text { (Rp.) }\end{array}$ & $\begin{array}{c}\text { Cummulated } \\
\text { Unlent } \\
\text { Deposits } \\
\text { (Rp.) }\end{array}$ & $\begin{array}{c}\text { Cumulated } \\
\text { Unclaimed } \\
\text { Reverse } \\
\text { Charges } \\
\text { (Rp.) }\end{array}$ & $\begin{array}{c}\text { Unclaimed } \\
\text { Reverse } \\
\text { Charges } \\
\text { per-unit of } \\
\text { Unlent } \\
\text { Deposit } \\
\text { (Rp.) }\end{array}$ \\
\hline \multirow[t]{2}{*}{1.} & 1.000 & 8 & 8 & & & & & & & & \\
\hline & & & & & & & & & 1.000 & 8 & 0,008 \\
\hline \multirow[t]{2}{*}{2.} & 3.000 & 10 & 30 & & & & & & & & \\
\hline & & & & & & & & & 4.000 & 38 & 0,0095 \\
\hline \multirow[t]{2}{*}{3.} & & & & 2.000 & 18 & 36 & 19 & 17 & & & \\
\hline & & & & & & & & & 2.000 & 19 & 0,0095 \\
\hline \multirow[t]{2}{*}{4.} & 2.000 & 6 & 12 & & & & & & & & \\
\hline & & & & & & & & & 4.000 & 31 & 0,00775 \\
\hline \multirow[t]{2}{*}{5.} & & & & 1.000 & 14 & 14 & 7,75 & 6,25 & & & \\
\hline & & & & & & & & & 3.000 & 23,25 & 0,00775 \\
\hline \multirow[t]{2}{*}{6.} & & & & 3.000 & 16 & 48 & 23,25 & 24,75 & & & \\
\hline & & & & & & & & & - & - & - \\
\hline TOTAL & 6.000 & & 50 & 6000 & & 98 & 50 & 48 & & & \\
\hline
\end{tabular}

Sumber: Zee (2014) setelah dimodifikasi 


\section{EVALUASI PERLAKUAN PAJAK PERTAMBAHAN NILAI JASA PERBANKAN DI INDONESIA}

Undang-Undang Nomor 8

Tahun 1983 tentang Pajak Pertambahan Nilai sebagaimana telah diubah beberapa kali, terakhir dengan Undang-Undang Nomor 42 Tahun 2009 pasal 4A menyebutkan jenis barang dan jasa yang dikecualikan dari pengenaan Pajak Pertambahan Nilai. Pada ayat (2) disebutkan jenis barang yang dikecualikan dari pengenaan Pajak Pertambahan Nilai, dan pada ayat (3) disebutkan jenis jasa yang dikecualikan dari pengenaan Pajak Pertambahan Nilai. Dari jenis-jenis jasa yang dikecualikan dari pengenaan Pajak Pertambahan Nilai, termasuk jenis jasa keuangan yang dicantumkan pada ayat (3) huruf $d$.

Di dalam penjelasan pasal $4 \mathrm{~A}$ ayat (3) huruf d diperinci jenis jasa keuangan yang dikecualikan dari pengenaan Pajak Pertambahan Nilai, yaitu meliputi: (a) jasa menghimpun dana dari masyarakat berupa giro, deposito berjangka, sertifikat deposito, tabungan dan atau bentuk lain yang dipersamakan dengan itu; (b) jasa menempatkan dana, meminjam dana, atau meminjamkan dana kepada pihak lain dengan menggunakan surat, sarana telekomunikasi maupun dengan wesel unjuk, cek atau sarana lainnya; (c) jasa pembiayaan, termasuk pembiayaan berdasarkan prinsip syariah, berupa sewa guna usaha dengan hak opsi, anjak piutang, usaha kartu kredit dan atau pembiayaan konsumen; (d) jasa penyaluran pinjaman atas dasar hukum gadai, termasuk gadai syariah dan fidusia; (e) jasa penjaminan.

Pengecualian yang diatur dalam Pasal 4A ayat (3) huruf d ini menunjukkan bahwa Indonesia seba- gaimana kebanyakan negara-negara lain di dunia yang menggunakan sistem Pajak Pertambahan Nilai juga mengecualikan jasa keuangan perbankan dari pengenaan Pajak Pertambahan Nilai. Namun sesuai dengan bunyi penjelasan dari pasal 4A ayat (3) huruf $\mathrm{d}$ ini jasa perbankan yang dikecualikan hanyalah jasa intermediasi keuangan, sedangkan jasa-jasa lainnya yang diberikan oleh bank akan tetap dikenakan Pajak Pertambahan Nilai.

Perkembangan yang ada di negara-negara lain yang menggunakan sistem Pajak Pertambahan Nilai, khususnya setelah terjadi krisis keuangan tahun 2008, menunjukkan adanya kecenderungan untuk menghapuskan pengecualian pengenaan Pajak Pertambahan Nilai untuk jasa intermediasi keuangan. Indonesia dalam masa krisis keuangan tahun 2008 memang tidak terlalu banyak terpengaruh terhadap terpaan badai krisis keuangan tersebut, walaupun ada kasus Bank Century. Namun diyakini setiap terjadi krisis keuangan, kondisi yang ada sering memaksa pemerintah suatu negara harus mengambil tindakan untuk penyelamatan banyak institusi keuangan termasuk perbankan dari ancaman kebangkrutan melalui program bail out atau semacamnya yang tentu saja akan sangat menguras kas negara. Hal ini harus dilakukan pemerintah, karena apabila institusi keuangan termasuk perbankan tidak diselamatkan dari kebangkrutan, maka akan berefek pada hilangnya dana masyarakat yang disimpan pada institusi perbankan tersebut dan hilangnya kepercayaan masyarakat terhadap lembaga perbankan. Dampak berikutnya adalah kegiatan ekonomi nasional akan terganggu dan menurun serta bisa mengakibatkan negara tersebut jatuh pada resesi 
ekonomi yang parah. Seperti yang terjadi di Amerika Serikat dan negaranegara Uni Eropa yang terkena dampak krisis keuangan tahun 2008. Contoh negara yang mengalami dampak terparah adalah Yunani.

Mengingat besarnya dana yang harus dikeluarkan pemerintah pada saat menyelamatkan institusi perbankan dan lembaga keuangan lainnya pada saat terjadi krisis keuangan, maka sudah seyogyanya kontribusi institusi perbankan dan lembaga keuangan lainnya terhadap penerimaan negara juga harus besar, khususnya kontribusi dari pembayaran pajak. Oleh karena itu menjadi tidak adil bila jasa intermediasi keuangan yang diberikan oleh perbankan dan lembaga keuangan lainnya dikecualikan dari pengenaan Pajak Pertambahan Nilai. Di samping itu pengecualian pengenaan Pajak Pertambahan Nilai terhadap jasa intermediasi keuangan menyebabkan timbulnya distorsi dari sudut legal maupun ekonomis.

Selama ini alasan satu-satunya pengecualian ini karena pengenaan Pajak Pertambahan Nilai terhadap jasa intermediasi keuangan perbankan sulit dilakukan disebabkan kesulitan menghitung penghasilan implisit dari jasa intermediasi keuangan. Jadi argumentasinya hanya suatu alasan yang sangat teknis, di mana seharusnya alasan teknis ini bisa dicarikan solusinya dengan menggunakan berbagai metode pendekatan yang diusulkan untuk pengenaan Pajak Pertambahan Nilai terhadap jasa intermediasi keuangan.

Oleh karena itu Indonesia ke depan sebaiknya juga harus mulai mempertimbangkan mengenakan $\mathrm{Pa}$ jak Pertambahan Nilai untuk jasa intermediasi keuangan perbankan ini, mengingat sektor perbankan adalah sektor yang sangat potensial untuk dikenakan Pajak Pertambahan Nilai. Apalagi dalam situasi target penerimaan pajak yang dalam tahun-tahun terakhir selalu tidak tercapai. Dalam hal ini Indonesia dapat menggunakan Modified Reverse Charging Method dari Zee (2004) untuk melakukan pemugutan Pajak Pertambahan Nilai untuk jasa intermediasi keuangan perbankan. Metode ini walaupun kelihatannya agak rumit, namun mempunyai sifat compatible dengan invoice credit method yang diterapkan untuk pemungutan Pajak Pertambahan Nilai bagi objek yang di luar jasa intermediasi keuangan. Jadi Pajak Pertambahan Nilai Masukan dari metode ini dapat dikreditkan dengan Pajak Pertambahan Nilai Keluaran dengan invoice credit method dan sebaliknya.

Dengan diberlakukannya pengenaan Pajak Pertambahan Nilai untuk jasa intermediasi keuangan, maka seluruh Pajak Pertambahan Nilai Masukan dari pihak perbankan, khususnya yang berkaitan dengan penyediaan jasa intermediasi keuangan akan dapat dikreditkan seluruhnya. Tidak seperti selama ini Pajak Pertambahan Nilai Masukan dari pihak perbankan sebagian besar tidak dapat dikreditkan. Mekanisme rantai pengkreditan Pajak Pertambahan Nilai yang selama ini terputus akan berjalan lagi sebagaimana mestinya.

\section{KESIMPULAN}

1. Pada saat terjadi krisis keuangan, pemerintah suatu negara umumnya terpaksa harus mengeluarkan dana yang besar untuk menyelamatkan institusi perbankan dari kebangkrutan.

2. Untuk jasa-jasa layanan yang diberikan oleh pihak perbankan, 
umumnya jasa intermediasi keuangan yang dikecualikan dari pengenaan Pajak Pertambahan Nilai, sedangkan untuk jasa-jasa lainnya telah dikenakan Pajak Pertambahan Nilai.

3. Pengecualian pengenaan Pajak Pertambahan Nilai terhadap jasa intermediasi keuangan mempunyai banyak efek negatif, antara lain mengurangi jumlah penghasilan negara dari sektor pajak dalam jumlah yang cukup signifikan, menimbulkan distorsi secara legal maupun ekonomis serta memutus rantai pemungutan Pajak Pertambahan Nilai.

4. Alasan utama jasa intermediasi keuangan dikecualikan dari pengenaan Pajak Pertambahan Nilai adalah karena adanya kesulitan untuk menghitung besarnya penghasilan implisit yang diperoleh perbankan dari jasa intermediasi keuangan tersebut.

5. Banyak metode pengenaan Pajak Pertambahan Nilai terhadap jasa intermediasi keuangan yang diusulkan, di mana sebagian besar dapat mengatasi kesulitan pengenaan Pajak Pertambahan Nilai terhadap jasa intermediasi keuangan.

6. Indonesia sampai saat ini masih mengecualikan pengenaan Pajak Pertambahan Nilai untuk jasa intermediasi keuangan perbankan.

\section{SARAN}

1. Untuk meningkatkan penerimaan dari sektor pajak dan menghilangkan berbagai distorsi secara legal dan ekonomis, maka Indonesia dapat menghapuskan peraturan pengecualian pengenaan Pajak Pertambahan Nilai untuk jasa intermediasi keuangan perbankan.
2. Di samping jasa keuangan perbankan, jasa-jasa intermediasi keuangan lainnya yang disediakan oleh lembaga keuangan non bank seperti usaha leasing, anjak piutang, kartu kredit, gadai, pembiayaan konsumen, pembiayaan/gadai syariah dan semacamnya seharusnya juga dikenakan Pajak Pertambahan Nilai, sehingga tidak menimbulkan adanya distorsi.

3. Jasa lainnya seperti jasa asuransi juga perlu dipertimbangkan untuk dikenakan Pajak Pertambahan Nilai.

\section{DAFTAR KEPUSTAKAAN}

Ardic, Oya Pinar, Maximilien Heimann and Nataliya Mylenko, 2011, Access to Financial Services and The Financial Inclusion Agenda Around The World: A Cross-Country Analysis With A New Data Set, Policy Research Working Paper 5537, The World Bank, Financial and Private Sector Development, Consultative Group to Assist The Poor.

Asmundson, Irena, 2011, What Are Financial Services?, Finance \& Development.

Boadway, Robin and Michael Keen, 2003, Theoretical Perspectives on The Taxation of Capital Income and Financial Services: A Survey.

Cottarelli, Carlo, 2010, Fair and Substantial - Taxing The Financial Sector, Financial Sector Taxation The IMF's Report to The G-20 and Background Material, International Monetary Fund. 
Erbe, Katharina and Thiess Buttner, 2013, FAT or VAT? The Financial Activities Tax as a Substitute to Imposing Value Added Tax on Financial Services, Econstor.

European Commission, Directorate General XXI Customs and Indirect Taxation, 1996, Value Added Tax: A Study of Methods of Taxing Financial and Insurance Services, A Study Carried Out for The European Commission by Ernst \& Young.

Feria, Rita De La and Michael Walpole, 2009, Options for Taxing Financial Supplies in Value Added Tax: EU VAT and Australian GST Models Compared, ICLQ Cambridge Journals, Vol. 58, page 897-932.

Feria, Rita De La and Richard Krever, 2013, Ending VAT Exemptions: Towards A Post-Modern VAT, Oxford University Centre for Business Taxation Said Business School, Park End Street, Oxford.

Gale, William G. and Benjamin $\mathrm{H}$. Harris, 2011, A VAT for The United States: Part of The Solution, Tax Analysts.

Holcombe, Randall G., 2010, The Value Added Tax: Too Costly for The United States, Working Paper No. 10-32, Mercatus Center, George Mason University.

Keen, Michael, 2011, Rethinking The Taxation of The Financial Sector, CESifo Economics Studies, Vol. 57, No. 1, page 1-24.

Keen, Michael and Ben Lockwood, 2007, The Value Added Tax: It's
Causes and Consequences, IMF Working Paper, Fiscal Affairs Department, International Monetary Fund.

KPMG, 2013, Proposals to Apply VAT to The Financial Services Sector in China.

Le, Tuan Minh, 2003, Value Added Taxation: Mechanism, Design and Policy Issues, Washington D.C.

Mackenzie, G.A., 1991, Estimating The Base of The Value Added Tax (VAT) in Developing Countries: The Problem of Exemption, IMF Working Paper.

Merrill, Peter R., 2011, VAT Treatment of The Financial Sector, Tax Analysts.

Mujeri, Mustafa Kamal, 2015, Improving Access of The Poor to Financial Services, A Report Prepared for The General Economics Division of The Planning Commission to Serve as A Background Study for Preparing The Seventh Five Year Plan (2016-2020) of Bangladesh.

Poddar, Satya and Morley English, 1997, Taxation of Financial Services Under A Value Added Tax: Applying The Cash Flow Approach, National Tax Journal, Vol. 50, No. 1, page 89-112.

Schenk, Alan, 2009, Taxation of Financial Services (Including Insurance) Under A United States Value Added Tax.

Smith, Andrew M.C., Ainul Islam and M. Moniruzzaman, 2011, Consumption Taxes in Developing Countries - The Case of The 
Bangladesh VAT, Working Paper No. 82, Centre for Accounting, Governance and Taxation Research, School of Accounting and Commercial Law, Victoria University of Wellington, Wellington, New Zealand.

Sutton, Christopher N. and Beth Jenkins, 2007, The Role of The Financial Services Sector in Expanding Economic Opportunity, Economic Opportinity Series, John F. Kennedy School of Government, Harvard University.

Undang-Undang Nomor 8 Tahun 1983 tentang Pajak Pertambahan Nilai Barang dan Jasa dan Pajak Penjualan atas Barang Mewah.

Undang-Undang Nomor 11 Tahun 1994 tentang Perubahan atas Undang-Undang Nomor 8 Tahun 1983 tentang Pajak Pertambahan Nilai Barang dan Jasa dan Pajak Penjualan atas Barang Mewah.
Undang-Undang Nomor 18 Tahun 2000 tentang Perubahan Kedua atas Undang-Undang Nomor 8 Tahun 1983 tentang Pajak Pertambahan Nilai Barang dan Jasa dan Pajak Penjualan atas Barang Mewah.

Undang-Undang Nomor 42 Tahun 2009 tentang Perubahan Ketiga atas Undang-Undang Nomor 8 Tahun 1983 tentang Pajak Pertambahan Nilai Barang dan Jasa dan Pajak Penjualan atas Barang Mewah.

Zee, Howell H., 2004, A New Approach to Taxing Financial Intermediation Services Under A Value Added Tax, IMF Working Paper, Fiscal Affairs Department, International Monetary Fund. 